\title{
WOMEN IN SCIENCE FICTION-ECHOES FROM AN UNINHIBITED WORLD
}

\author{
Barnali Chetia \\ Indian Institute of Information Technology, Vadodara (IIITV), India
}

\begin{abstract}
From the shelves devoted to Frankenstein in a book store to the possible Artificial Intelligence revolution in Ex-Machina in a multiplex theatre, science fiction has travelled some distance. Till date the exact definition of science fiction remains contested. This genre is still exploring the potential of retelling a fictitious tale of time, space, genetics, technology and experience. Infact science fiction as a genre of literature distinguishes itself from others by its portrayal of a world of imaginationutopia/dystopia. This genre plays an important role in society as it talks about an alternative world of possibilities, possibility of an equal world, where one can critique gender roles, traditions and values. A medium of communication to debate sex roles, life and changes. Post 1960s, after the women's liberation movement, changes were witnessed in the social, cultural, political and economic life of women and with this science fiction, the so called male dominated genre, also experiened changes. The popular belief of women writing only sorcery and fantasy was fading. This paper is an empirical study of women science fiction writers questioning the gender roles and advocating a social change in their fictitious worlds.
\end{abstract}

Keywords: Science Fiction, Women, Gender Roles, Change

\section{INTRODUCTION}

"I want to be free... I want, I think, to be omniscient... I think I would like to call myself 'the girl who wanted to be God'. Yet if I were not in this body, where would I be--perhaps I am destined to be classified and qualified. But, oh, I cry out against it."

-- Sylvia Plath, Letters Home (1975)

In a so called male dominated genre, Mary Shelley, the woman writer pioneered with her novel Frankenstein; or, The Modern Prometheus at the age of nineteen. Frankenstein was published in the year 1818. That was the time when society expected much from science, people were in a path of constant search for knowledge. It is witnessed even in the protagonist of the novel. In her work, Shelley questions the thoughtless development of science. In Frankenstein the male characters were of primary focus. The narrator Robert Walton, the protagonist Victor Frankenstein, Victor's father Alphonse Frankenstein, and brothers William and Earnest, Henry Clerval -his best friend, and finally the monster which Victor Frankenstein creates, are all male figures. Shelley did a wonderful job of portraying women of this era, where they were seen as possessions for men, protected by men, diligently carrying out their duties of mother, daughter, wife and sister. In what is considered to be the first novel in the genre of science fiction, Shelley used Caroline Frankenstein, Justine Moritz, Elizabeth Lavenza, Safie, Mrs. Saville, and not to forget the female monster that Victor begins to create.

Caroline Frankenstein is portrayed as the damsel in distress, when she is rescued by Alphonse Frankenstein after her father's death. Caroline later on becomes the wife of Alphonse and mother of Victor. Caroline, the dutiful daughter, nurses her father Beaufort until his death. She is portrayed as the epitome of a perfect woman of that century displaying the qualities of a nurturer, bearer and selflessness. She was the sacrificial caregiver who subsequently dies doing her duty. Elizabeth Lavenza, the ideal sister, cousin and future wife to Victor, was the orphaned child who was rescued and adopted by

Corresponding Author: bchetia03@gmail.com, barnali@iiitvadodara.ac.in 
the Frankensteins'. Her character was described as a passive one and we see her strength once in the novel when she stood up for Justine's innocence. Justine Mortiz, the character with immense potential, was not given the scope to be explored by the readers. She was a faithful and caring servant. Shelley reiterated by the treatment to her character that women cannot speak for oneself and society decides her fate. In this novel, from a clever, gentle and extremely pretty lady she is turned into a witch and executed for the murder of William Frankenstein. The other two characters, Mrs. Saville and Safie, has minimum purpose in the novel.

Shelley echoing the voices of the society treated the women characters as secondary ones. By making her protagonist Victor Frankenstein create or rather procreate, the biological aspect of reproduction was questioned, where females had no role to play. Victor was trying to become God by deciding whom to bring to this world and whom not, his decision of not creating a mate for the monster emphasizes that. The union of men and women were not required to bring in future children. Women during that century were considered powerless and submissive which is rightly reflected in the novel.

Jane C. Loudon's The Mummy!: A Tale of the Twenty-Second Century, was a futuristic meditation on England. Published anonymously in three volumes in 1827, she hoped technology and social progress would improve in her country, she questioned whether the monarch and church should be abolished and whether Positivism and technology would bring in better changes in the society. It's also a take on the othering of non-Western countries, a trend that became prominent during the British Empire which began with Napoleonic discoveries of pharaonic tombs. Her work was a dismissal of the socialism of Romantic movement.

In the beginning of the book, Queen Claudia reigns. The plot includes two aristocratic families who have their eyes on the crown and glory: the Montagues and the house of the Duke of Cornwall. The Montague family has two sons, Edmund, a national hero on the fast-track to knighthood, and Edric, an intellectual. The Duke of Cornwall's family features marriageable daughters Elvira and Rosabella who are also the next in line to the throne if anything happened to the Queen.

Overshadowed by his brother's achievements, Edric yearns for his own glory within the intellectual domain, and captivated by the idea of reanimation hatches a plan with his friend, German scientist, Dr. Entwerfen, to resurrect a mummy. Cheops is the Frankenstein of Loudon. Like Shelley Loudon's creation is also male and not purely evil-and, in fact, is a complex archetype used to subvert the Orientalism of Egyptomania when Napoleon's troops discovered their first pharaonic tomb. Edric represents a more thoughtful and conscientious vein of mad science. He is not interested in making a man, or recreating life, but in uncovering the divine with scientific experimentation. His research poses the age old philosophical question of what happens to the soul upon death. This is a debate he isn't at all fearless about; he worries whether resurrecting a corpse might result in a soulless zombie than a real man. Taking a slight detour from the main plot, we discover the world Loudon is talking about to her readers in the sub plot, a world which is undergoing popular revolt, spiritual disillusionment, and a long and disastrous flirtation with republicanism, England returns to absolute monarchy and Catholicism. Matriarchy takes over. When the new conservative regime was reestablished, the male heir to the throne refused to wear the crown; his daughter wore it and ruled England with the ruthlessness of Queen Elizabeth I. Feminism though latent in the main plot works actively in the sub plot.

Mizora: A Prophecy by Mary E Bradley Lane (1890) is the second known feminist utopian novel written by a woman. This novel encourages the concept of an all-female society where women doesn't need man for procreation. Vera Zarovitch was the narrator of the story, who was shown to be a young wife and mother. The novel's backdrop was the Polish revolt of 1863 . Vera Zarovitch was found guilty and was sentenced to exile in Siberia by the Czarist regime. In her attempt to escape northward into the Artic, her kayak by accident reaches Mizora. In Mizora, she learned their ways and culture, and planned to teach her own society what she has learned. She spends fifteen years of her life there. An interesting feature in the novel was refuting the norm of expectation from the women in Mizora. Unlike the world then where the norm was 
to wear tightly-corseted dresses to flaunt their narrow waists, in Mizora, narrow waists were considered a disgusting deformity (in the words of the writer).

Charlotte Perkins Gilman's Herland (1915) is another utopian novel. The story talks about an isolated allfemale society where again like Bradley's Mizora men are not required for procreation. But unlike Bradley's Mizora, the story of Herald is told from the perspective of men. Vandyck Jennings, a student of sociology is the protagonist of the story. Jennings forms a group to explore an area of Godforsaken land where the belief is that of a society consisting entirely of women. Gilman along with telling a beautiful story to her readers was also hinting at society and its beliefs. She defined how gender roles are socially constructed, how an all-female society give up their children to the care of another questioning the age old child- rearing process, and how children are not given the bondage of their last names. In Gilman's fictional world, she reverses the stereotypical gender roles: where women are depicted with short hair, the men have long hair; the women is depicted as a teacher while the men as a learner; and further, the women are depicted physically stronger than the men,

Thea Von Harbou's Metropolis (1925) is about a story set in 2026 in a technologically advanced city, which is sustained by the existence of an underground society of labourers. Problems arose in the story when the son of one of the city's founders falls in love with a girl from the underground society. We witness an early Robot in the form of Maria. The story was not an exceptional one. The city Metropolis is a fictional city, effectively a dictatorship, ruled by the protagonist's father. Again, Shadow on the Hearth (1950) by Judith Merril seems like a saga of nuclear scare nostalgia. The protagonist of the story, Gladys Mitchell, is not a scientist or physicist or someone eminent. She by no means has the potential to become a threat for the humankind. Infact the story begins with an overtly domestic scene, as Gladys washes her family's laundry, and also worriying about the social development of the people. This story is more about a Westchester woman and her two children after the explosion of a series of atomic bombs on New York.

The Birthgrave by Tanith Lee (1975) begins with a nameless female narrator awakening inside a volcano with no idea who she is. The story has a glistening jade which may hold answers to her queries on her past and true identity. Its ironical how emerging from the volcano make her a Godess in the eyes of the villagers. This story is more of the triumph of good over evil as our protagonist fights the deceitful Vazkor and in the end kills him. Lee uses computers of a spaceship to reveal the narrator's forgotten past. Lee echoing with fantasy let us know that Karrakaz was our protagonist's creation as an alternate personality to destroy her. In Lee's fictional world, in the end, from the eyes of Karrkaz, we witness a face behind the mask, which was unimaginably beautiful.

Ursula K. Le Guin's first novel Rocannon's World (1966) tells the story of Gaveral Rocannon, an ethnologist who had met Semley at the museum and he later goes on an ethnological mission to her planet, Fomalhaut II. Guin before giving her readers a chance to peep in Rocannon's life ushered us into the life of Semley. The prologue of the novel begins with a young woman named Semley. It is about her space voyage to a museum from her unnamed, technologically primitive planet, to reclaim a family heirloom. The journey which apparently looked like a short trip to her took away many years from her life without her realisation. When she returned to her planet she found her daughter grown up and husband dead. In Guin's most famous book The Left Hand of Darkness (1969), she talks about social relations in a society where gender is irrelevant. Readers saw as a homophobic depiction of the relationship between Estraven and Ai. Genly Ai in the novel struggles to form a bond with Estraven, and the barrier between them was finally broken down during their journey on the ice, when he recognizes and accepts Estraven's dual sexuality. This new intimacy made their bonding strong and Genly Ai taught Estraven to mindspeak. Heterosexuality was the norm shown in the planet Gethen. The inhabitants of Gethen through their androgynous nature examined gender relations in human society. Critics say that her book was her way of gently critiquing masculinity. And absence of gender divisions leads to a society without the constriction of gender roles.

The Female Man (1975) by Joanna Rus is a feminist science fiction where the characters Joanna, Janet, Jael and Jeannine's (all from different parallel worlds) perspectives are expressed in the form of common 
conversations which demonstrate their frustration with men's ignorance of women. The Female Man has four distinct settings, each of them an alternate version of our very own Earth. Joanna, Jeannine, and Janet have arrived in Jael's world which is experiencing a long war (around forty years) between male and female societies. Jael explains that she works for the Bureau, an organization that concentrates on people's various counterparts in different parallel worlds. She reveals that she is the one who brought all of them together because they are essentially "four versions of the same woman" (1975:162). Jael finally tells the other women the truth of assembling all of them. She wanted to create bases in the other women's worlds without the knowledge of the male society and eventually empower women to overthrow oppressive men and their gender roles for women. The novel ends with the women separating and returning to their respective worlds, each with a new perspective on her life, her world, and her identity as a woman.

Published in the year 1980 by Octavia Butler, Wild Seed is the story Doro and Anyanwu, two immortal mutants. Anyanwu is Butler's black female protagonist who is born in Africa with genetic mutations that endow her with immortality and physical strength. She is a "shape-shifter," someone who is capable of altering her cells to create a new identity such as a different body, sex, age, or even species. Anyanwu is a highly moral woman with a strong sense of humanity. Important to Anyanwu are family and community, autonomy and companionship, love and freedom. Unlike Anyanu, Doro is introduced in the novel as the antagonist. He is a mutant, born in Egypt during the reign of the Pharaohs. As he approaches puberty, Doro learns quite accidentally that he is a "body snatcher," meaning that his life can be extended by killing the nearest person to him and subsuming his/her physical body. His immortality is rather snatched from other humans. Doro utilising his power was using Anyanwu to breed; tired of Doro when she planned to commit suicide, there is a change of heart in Doro and he stops Anyanu to breed. The story ends at a note where Anyanu decides to help him in his quest to find more promising seeds, but as an ally and partner than his slave.
He, She and It by Marge Piercy (1991) talks about a town called Tikva founded by the Jews after a long period of persecution. Tikva exists in a kind of dome over what used to be the Northeastern United States. The story is about the protagonist Shira who returns to her hometown Tikva and starts working on the socialization of the cyborg, who has been created illegally by Avram to protect the city. Yod is a cyborg whose programming has partially been completed by Malkah, Shira's grandmother. The sexual relationship between Shira and Yod pioneered a new thought in the genre. Again, Nalo Hopkinson's dystopian novel Brown Girl in the Ring (1998) takes place in a walled-off inner city filled with crime, drug addiction, and poverty, where the causes of the city's downward spiral are economic. In the novel, conditions worsen when those with money flee from the city to the suburbs. In this situation, Ti-Jeanne, the female protagonist, is shown trapped and injected with Buff, a drug that paralyzes her. While in a state of paralysis, she slips into an "astral" state, and she calls upon the ancestor spirits to help her. And these spirits helps her in getting justice. With folklore and magic realism the novel is a reflection of the AfroCaribbean culture.

Lisa Goldsteins The Uncertain Places (2011) is the story of two friends from the turbulent 1960s, Will and Ben, both UC Berkeley undergraduates, fall into company with a quirky family of Napa wine-growers, the Feierabends. Will and Ben get romantically connected to the two eldest Feierabend daughters. The duo perceive that theres something uncanny about the family. The reader unravels, through a series of fairytales set in 19th century Germany, Depression-era California, Summer of Love Berkeley, and the greed-is-good 1980s. The world portrayed in The Uncertain Places is the one borrowed straight from Grimm's Fairy Tales. Justina Robson's The Glorious Angels (2015) focuses mainly on the lives of Tralane Huntingore and her daughters Minnabar and Isabeau. The readers do get to see each of these characters being tested in difficult circumstances. There is a sense of mistrust between the major protagonists throughout the novel. The unique feature was that the Empire is ruled by eight Empresses each with different personalities, skills and goals. Each rule a different city of the Empire, but are connected by something more than telepathy, which doesn't mean that they are all in constant 
agreement, with some of the Empresses more dominant than others. The World portrayed in The Glorious Angels is the one which is run by women and the men of the Empire are allowed a certain amount of power in specific fields. Its a world with constant struggle for power and intrigue.

Breaking the stereotypes, most women writers in science fiction are focussing on female characters who are more concerned about academics or careers and not appearences and romantic entanglements. Traditional stereotypes of women as passive, dependent and emotional beings are broken with counter-stereotypical descriptions of women. Roles of a woman is socially constructed and externally imposed which forces one to operate in a certain kind of behaviour and appearance. This limits freedom and constrains the potential of the women. In the fictitious world of these science fiction writers social norms are entirely decoupled from potential reproductive function. Infact they were talking of an alternative world, an all-female society, where women doesn't need man for procreation. Being female or male had as little bearing on how one is expected to dress and behave. She was fairly represented in the political system. Unlike the nonfictional world, submission and subordination didn't define women. Many a times even the concept of gender was abolished in their world. To sum up, nothing can be more apt then the words of Ursula K. Le Guin (1974) If science fiction has a major gift to offer literature, I think it is just this: the capacity to face an open universe. Physically open. psychically open. No doors shut.

\section{REFERENCES}

Asimov, Isaac. Asimov on Science Fiction. Garden City, NY: Doubleday \& Company, 1981.

Barr, Marleen. Feminist Fabulation: Spucr/Postmodem Fiction. Iowa City: University of Iowa Press, 1992.

Butler E. Octavia. Wild Seed. Doubleday Books, 1980.

Fuss, Diana. Essentially Speaking: Feminism, Ntltnre \& Difference. New Y ork: Routledge, 1989.
Goldstein, Lisa. The Uncertain Places. Tachyon Publications, 2011.

Gilman, P. Charlotte. Herland. Pantheon, 1915.

Haraway, Donna Simians, Cyborgs and Women: The Reinvention of Nature. London: Free Association Book, 1991 .

Hawthorn, Jeremy. A Glossary of Contemporary Literary Theory. London: Arnold. 1998.

Harbou, V. Thea. Metropolis. Illustrietes Blatt, 1925.

Hopkins, Nalo. Brown Girl in the Ring. Grand Central Publishing, 1998.

Lane, Bradley E Mary. Mizora: A Prophecy. New York, G. W. Dillingham, 1890.

Loudon C. Jane. The Mummy!: A Tale of the TwentySecond Century. University of Michigan, 1995.

Le Guin, Ursula K. Dancing at the Edge of the World: Thoughts on Words, Women. Places. New York: Grove Press, 1989.

Le Guin, Ursula K.The Left Hand of Darkness. New York: Ace Science Fiction Books, 1969.

Le Guin, Ursula K. Roccanon's World. Ace publishers, 1966.

Lee Tanith. The Birthgrave. Orbit Publishers. 1977.

Merril, Judith. Shadow on the Hearth. Garden city: Doubleday, 1950.

More, Thomas. Utopia. 15 16. Eds. George Logan and Robert Adms. Cambridge: Cambridge University Press, 1989.

Piercy, Marge. He, She and It. New York: Fawcett Crest, 1991.

Reid, Robin Anne. "Stealth Feminism." Feminist Science Fiction, Fantasy, \& Utopia Listserv. feministsf @ listserv.uic.edu (April 12, 1999).

Roberts, Robin. A New Species: Gender and Science in Science Fiction. Chicago: University of Illinois Press, 1993.

Robson, Justina. Glorious Angels. London: Gollancz, 2015.

Russ, Joanna. The Female Man. Boston: Beacon Press, 1975.

Shelley, Mary Wollstonecraft. Frankenstein, or. The Modern Pronetheus. L 823. Oxford: Woodstock Books, t 993.

Stockwell, Peter. "Introduction." Impossibility Fiction: Alternativity Extrapolation, Speculation. Eds. Derek Littlewood and Peter S toc kwell. Amsterdam: Rodopi Books, 1996. 3-9.

Woodman, Marion, and Elinor Dickson. Dancing in the Flames: The Dark Goddess in the Transformation of Consciousness. Toronto: Vintage Canada, 1996 